Publisher: Faculty of Agronomy Čačak

\title{
Detection of enzymes produced by lactic acid bacteria isolated from traditionally made Serbian cheese and their role in the formation of its specific flavor
}

\author{
Mirjana Ž. Grujović1* ${ }^{*}$ Katarina G. Mladenović1 ${ }^{1}$ Violeta D. Jakovljević ${ }^{2}$ Ljiljana R. Čomić1 \\ ${ }^{1}$ University of Kragujevac, Faculty of Science, Department of Biology and Ecology, Radoja Domanović 12, 34000 \\ Kragujevac, Serbia \\ 2Department of Biomedical Science, State University of Novi Pazar, Vuka Karadzića bb, Novi Pazar, Serbia \\ *Corresponding author: mirjana.grujovic@pmf.kg.ac.rs
}

Received 23 January 2020; Accepted 24 November 2020

\begin{abstract}
A B S T R A C T
Nine species (sixteen isolates) of lactic acid bacteria (LAB) isolated from traditionally made Serbian cheese were evaluated for their enzymatic activities in order to select indigenous strains of technical interest for the manufacture of cheese. These strains were selected based on their previously determined biochemical and physiological characteristics, as well as their antimicrobial activity, and were identified as Lactococcus lactis subsp. lactis (one isolate), Lc. lactis subsp. lactis biovar. diacetylactis (five isolates), Lactobacillus fermentum (two isolates), Lb. plantarum (one isolate), Lb. brevis (one isolate), Enterococcus faecalis (three isolates), E. faecium (one isolate), E. durans (one isolate) and E. hirae (one isolate). The enzymatic activities (acid and alkaline invertases, alkaline phosphatase, alkaline protease, $\alpha$-amylase) were measured by using the spectrophotometric method. The results indicated that all Lactobacillus isolates showed protease, amylase, and alkaline phosphatase activities, while the activities of acid and alkaline invertases were not observed. The Lactococcus isolates showed protease, acid invertase and alkaline phosphatase activities, except the KGPMF50 isolate, which showed no alkaline phosphatase activity. The tested Enterococcus isolates showed weakly and strain-specific enzymatic activity. The results indicated that the enzymes produced by the investigated strains have a role in the formation of the specific flavor of cheese and that these isolates, especially Lactobacillus isolates, showed the potential for use in the dairy industry or applied biotechnology.
\end{abstract}

Keywords: enzymatic activity, lactic acid bacteria, traditionally made cheese, biotechnology, dairy industry.

\section{И 3 В $О$ Д}

Циљ овог рада био је испитивање способности продукције ензима девет одабраних врста (16 изолата) бактерија млечне киселине (БМК) изолованих из српског сира произведеног на традиционалан начин, како би се утврдило који аутохтони сојеви имају технолошки утицак у процесу производње сира. Изолати су одабрани на основу претходно утврђених биохемијских и физиолошких карактеристика, као и антимикробне активности и идентификовани су као: Lactococcus lactis subsp. lactis (један изолат), Lc. lactis subsp. lactis biovar. diacetylactis (пет изолата), Lactobacillus fermentum (два изолата), Lb. plantarum (један изолат), Lb. brevis (један изолат), Enterococcus faecalis (три изолата), E. faecium (један изолат), E. durans (један изолат) и E. hirae (један изолат). Ензимска активност, која је обухватала детекцију киселе и алкалне инвертазе, алкалне фосфатазе, алкалне протеасе и $\alpha$-амилазе, је одређена коришћењем спектрофотометра. Резултати указују да су сви изолати Lactobacillus показали активност протеазе, амилазе и алкалне фосфатазе, док активност киселе и алкалне инвертазе није примећена. Изолати лактокока су показали активност протеазе, киселе инвертазе и алкалне фосфатазе, осим изолата KGPMF50, који није показао активност алкалне фосфатазе. Испитани изолати ентерокока показали су слабу и изолат специфичну ензиматску активност. Резултати указују да продуковани ензими испитиваних изолата имају улогу у формирању специфичног укуса сира и да сви изолати, посебно изолати из рода Lactobacillus, показују потенцијал за примену у млечној индустрији или у примењеној биотехнологији.

Кључне речи: ензимска активност, бактерије млечне киселине, традиционална произведња сира, биотехнологија, млечна индустрија.

\section{Introduction}

Traditional cheeses, made from raw, unpasteurized milk, without adding any bacterial starter cultures or rennet of animal origin, are the source of autochthonous lactic acid bacteria (non-starter LAB). In these cheeses, bacterial enzymes can affect maturation, color, texture, flavor, and nutritional value. They are mainly used in the food industry to optimize the process, improve efficiency, quality, shelf life, and, most importantly, to achieve the desired organoleptic characteristics of the final product (Avendaño et al., 2016).

The LAB isolated from Sokobanja cheese showed antimicrobial potential and great acidification ability in previous studies (Muruzović et al. 2018a; 2018b). Liu et al. (2013) indicated that LAB has the ability to produce some useful enzymes. Wijesundera et al. (1997) found that lactobacilli can enhance proteolysis and improve flavor formation in cheese. The metabolic and enzymatic potentials of non-starter LAB lie in their dominance in total viable microorganisms in cheeses 
(Peterson et al., 1990) and their metabolic versatility (Fox et al., 1998). So far, enzymatic activity has been studied mainly for LAB isolated from wine (Mtshali 2007). But, Novik et al. (2007) and Patel et al. (2012) indicated that some species of Lactobacillus, Lactococcus, Pediococcus, and Bifidobacterium isolated from fermented foods have the ability to produce carbohydrate degrading enzymes. It is known that fermented kinds of milk can be supplemented with some probiotic strains. Fermented milk manufactured in this way can be made more functional in human nutrition (Patel et al., 2013). Furthermore, if LABs are capable of synthesizing essential biomolecules (vitamins, enzymes, or bacteriocins), they can affect the functional and technological properties of the food products.

This study aimed to evaluate the enzymatic activity (acid and alkaline invertases, alkaline phosphatase, alkaline protease, invertase) of sixteen LAB isolates from traditionally made cheese from Southeastern Serbia (Sokobanja area) to find their role in the specific flavor of the cheese.

\section{Materials and methods}

\section{Isolates used in the study}

The tested strains of LAB were isolated from threeday-old Sokobanja cheese (Muruzović et al., 2018a; 2018b; Grujović et al., 2019). The strains were isolated during different sampling seasons (spring, summer, and autumn) from different culture media and were identified to the genus level by physiological and biochemical tests. Then, sixteen strains were chosen, based on their antimicrobial activity relative to five indicator strains (Escherichia coli ATCC 25922, Proteus mirabilis ATCC 12453, Klebsiella oxytoca KGPMF1, Klebsiella ornithinolytica KGPMF8, and Aeromonas hydrophila). The chosen strains of LAB were identified as Lactococcus lactis subsp. lactis (one strain), Lc lactis subsp. lactis biovar. diacetylactis (five strains), Lactobacillus fermentum (two stains), $L b$. plantarum (one strain), Lb. brevis (one stain), Enterococcus faecalis (three strains), E. faecium (one strain), E. durans (one strain), and E. hirae (one strain), by using MALDI-TOF mass spectrometry. The strains were frozen at $-80^{\circ} \mathrm{C}$ in MRS broth with $20 \%$ glycerol. They were subcultured in the same medium at $37^{\circ} \mathrm{C}$ for $16-24 \mathrm{~h}$ before the various assays were performed.

\section{Screening of LAB for their proteolytic and lipolytic activity}

The proteolytic activity of LAB was examined according to Harrigan and McCance (1976), with some modifications. The substrate was formed by mixing MRS agar medium and milk (1.6\% fat) in a ratio of $1: 1$. The inoculated media were incubated at $37^{\circ} \mathrm{C} / 24 \mathrm{~h}$. The appearance of a clear zone around the colonies of bacteria confirmed their proteolytic activity. Bacillus subtilis ATCC 6633 and Escherichia coli ATCC 25922 were used as positive and negative control, respectively.

The lipolytic activity of bacteria was examined according to Harrigan and McCance (1976), with some modifications. The substrate was formed by adding an egg yolk (4\%) into the MRS agar. The inoculated media were incubated at $37^{\circ} \mathrm{C} / 24 \mathrm{~h}$. The appearance of an opalescent zone around the colonies of bacteria confirmed their lipolytic activity. B. subtilis ATCC 6633 and E. coli ATCC 25922 were used as a positive and negative control, respectively.

\section{Preparation of fermentation liquids of LAB}

Strains of isolates were grown in $10 \mathrm{ml}$ of MRS broth $(1 \%$ inoculum $)$ at $37^{\circ} \mathrm{C}$ for $24 \mathrm{~h}$ until they had reached the stationary phase (Kenny et al. 2003). The cultures were then centrifuged at $10000 \mathrm{rpm}$, for 30 $\min$, at a temperature of $4^{\circ} \mathrm{C}$. The fermentation liquid supernatants were separated and frozen at $-20^{\circ} \mathrm{C}$ until use. The enzymatic activities were tested from these samples.

\section{Evaluation of enzymatic activities}

\section{Determination of acid and alkaline invertase activities}

Invertase activity was determined by the method described in Sumner and Howell (1935) with some modifications. The determination of alkaline invertase activity in the fermentation liquid of the isolates involved the preparation of a reaction mixture containing $0.5 \mathrm{ml}$ of crude enzyme extract, $0.5 \mathrm{ml}$ of $0.02 \mathrm{M}$ phosphate buffer ( $\mathrm{pH} \mathrm{8.0)}$ ), and $1 \mathrm{ml}$ of $1 \%$ $(\mathrm{w} / \mathrm{v})$ of sucrose. The contents of the tube (sample) were mixed and incubated in a water bath at $37^{\circ} \mathrm{C}$ for $15 \mathrm{~min}$. In the second (control) tube, the same ingredients were added as in the test tube, and that tube was placed on ice until the incubation of the test tube was completed. One ml aliquots of the contents of both tubes were taken and $2 \mathrm{ml}$ of the dinitrosalicyl reagent was added. The test tubes were incubated at $100^{\circ} \mathrm{C} / 5 \mathrm{~min}$. The tubes were cooled at room temperature and the amount of liberated reducing sugars was spectrophotometrically determined at 540 $\mathrm{nm}$ (Miller, 1959). The enzymatic activity of acid invertase was determined in the same way in a reaction mixture containing $0.5 \mathrm{ml}$ of crude enzyme extract, 0.5 $\mathrm{ml} 0.01 \mathrm{M}$ sodium acetate buffer $(\mathrm{pH} 4.5)$, and $1 \mathrm{ml}$ of $1 \%(\mathrm{w} / \mathrm{v})$ sucrose. The invertase activity unit (IU) is defined as the amount of enzyme which catalyzes the production of $1 \mu \mathrm{M}$ of glucose per minute at $37^{\circ} \mathrm{C}$.

\section{Determination of alkaline phosphatase activity}

The enzymatic activity of alkaline phosphatase was determined based on the amount of inorganic phosphorus, using Allen's method (Allen 1940) with some modifications. The enzymatic activity was measured in a reaction mixture containing $1 \mathrm{ml}$ of glycol buffer $(\mathrm{pH} 9.0)$ with $\mathrm{Mg}^{2+}, 1 \mathrm{ml}$ of enzyme extract, and $1 \mathrm{ml}$ of $\beta$-glycerophosphate (substrate). The tubes containing the reaction mixture were incubated at $37^{\circ} \mathrm{C} / 30 \mathrm{~min}$. After the incubation, the enzyme reaction was interrupted with the addition of 3 $\mathrm{ml}$ of $10 \%$ TCA. The tubes were placed on ice for 15 minutes, after which the contents of the tubes were filtered, and the filtrate was collected. Control tubes were prepared in the same way, but without incubation, TCA was immediately added, and the tubes were held on ice for $15 \mathrm{~min}$ and filtered. To determine the concentration of phosphorus in the sample, Allen's reaction was performed. One $\mathrm{ml}$ aliquots of both the test and control filtrates were poured into two tubes, and $0.4 \mathrm{ml}$ of amide, $0.4 \mathrm{ml}$ of $60 \%$ PCA, $0.2 \mathrm{ml}$ of $\mathrm{NH}_{4}$ - 
molybdate, and $3 \mathrm{ml}$ of distilled water were added to each tube. The tubes were incubated at room temperature, for $11 \mathrm{~min}$. The absorbance of prepared solutions was measured at $720 \mathrm{~nm}$.

\section{Determination of alkaline protease activity}

The proteolytic activity of the fermentation liquid was determined based on the presence of enzymes in 1 $\mathrm{ml}$ of the liquid medium by Anson's method (Anson 1938) with some modifications, based on the amount of tyrosine liberated by the hydrolysis of casein under the action of proteolytic enzymes. The proteolytic activity of the fermentation liquid was determined as follows: 1 $\mathrm{ml}$ of the fermentation fluid was added to one tube, and $5 \mathrm{ml}$ of $2 \%(\mathrm{w} / \mathrm{v})$ solution of casein was added to another tube. Both tubes were heated in a water bath at $37^{\circ} \mathrm{C} / 15 \mathrm{~min}$. Thereafter, $2 \mathrm{ml}$ of heated casein in the test tube was mixed with the fermentation liquid (test) and returned to incubate for another $10 \mathrm{~min}$. The enzyme reaction was stopped by the addition of $5 \mathrm{ml}$ of cold 5\% (w/v) trichloroacetic acid (TCA). The mixture was blended and then passed through filter paper. In another control tube, $1 \mathrm{ml}$ of the fermentation fluid was pipetted and $2 \mathrm{ml}$ of cold casein and $5 \mathrm{ml}$ of $5 \%(\mathrm{w} / \mathrm{v}$ ) TCA were immediately added. The mixture was blended and then passed through filter paper. Two ml of the filtrate was taken from the test and control tubes, and separated, following which $5 \mathrm{ml}$ of $6 \%(\mathrm{w} / \mathrm{v})$ $\mathrm{Na}_{2} \mathrm{CO}_{3}$ and $1 \mathrm{ml}$ of Folin-Ciocalteu reagent were added to each filtrate. The mixture from the tubes was blended and left at room temperature /30 min until the blue color had developed. In a separate tube (blank), 1 $\mathrm{ml}$ of distilled water was placed instead of tyrosine and all other ingredients were added. The absorbance value was read on the spectrophotometer at $660 \mathrm{~nm}$.

\section{Determination of $\alpha$-amylase activity}

The Bernfeld method (Bernfeld 1955), with some modifications, was used to determine $\alpha$-amylase activity. The activity of $\alpha$-amylase in the fermentation liquid was determined by the preparation of a reaction mixture containing $0.5 \mathrm{ml}$ of crude enzyme extract, 1.5 $\mathrm{ml}$ of buffer (pH 6.9) (20 mM sodium phosphate, and $6.7 \mathrm{mM} \mathrm{NaCl})$ and $1 \mathrm{ml}$ of $1 \%(\mathrm{w} / \mathrm{v})$ starch. The contents of the tube (sample) were mixed and incubated in a water bath at $37^{\circ} \mathrm{C} / 15 \mathrm{~min}$. In the control tube, the same ingredients were added as in the test tube, and the tube was placed on ice until the incubation of the test tube was completed. One $\mathrm{ml}$ aliquots of the contents of both tubes were taken and 1 $\mathrm{ml}$ of dinitrosalicyl reagent (5.3 M K-Na-tartrate and 96 $\mathrm{mM}$ of 3,5-dinitrosalicylic acid) was added. The test tubes were incubated at $100^{\circ} \mathrm{C} / 15 \mathrm{~min}$. The tubes were cooled to room temperature and then the absorbance was spectrophotometrically read at $540 \mathrm{~nm}$.

\section{Statistical analysis}

All data for measuring the amount of enzymes were presented as means \pm standard deviations using Microsoft Excel (Redmond, Washington, DC, USA). Statistics 20. ANOVA analysis (SPSS Inc., Chicago, IL, USA) was carried out to determine statistical differences $(\mathrm{p}<0.05)$ between the different bacterial strains of the same genus with respect to the values of acidification and enzyme activity. The strains were tested three times for each enzymatic activity.

\section{Results and discussion}

\section{Screening for proteolytic and lipolytic activity}

As revealed by the results of screening for proteolytic and lipolytic activity, isolates from the genera Lactobacillus, Lactococcus and Enterococcus did not exhibit lipolytic activity, but they showed proteolytic activity. Exceptions were isolates from the genus Enterococcus, because they did not show sufficiently clear results related to proteolytic activity when compared with the positive (B. subtilis ATCC6633) and negative (E. coli ATCC 25922) controls. Therefore, in the next part of the experiments, lipolytic activity was not investigated.

\section{The enzymatic activities of isolated lactic acid bacteria}

The enzymatic activities of four isolates of the genus Lactobacillus were investigated and the results are presented in Table 1. All isolates showed protease, amylase, and alkaline phosphatase activities, while the activities of acid and alkaline invertases were not observed. The activity of protease was significant, compared with the other tested enzymes $(p<0.05)$. Isolate $L b$. fermentum KGPMF28 showed the best enzymatic activity among all lactobacilli.

The enzymatic activities of six isolates of the genus Lactococcus were investigated and the results are presented in Table 1. All isolates showed protease, acid invertase, and alkaline phosphatase activities, except KGPMF50, which showed no alkaline phosphatase activity. The activities of alkaline invertase and amylase were not observed. The activity of protease was significant, compared with the other tested enzymes ( $p$ $<0.05$ ). The enzymatic activity among all lactococci was strain specific.

The enzymatic activities of six isolates of the genus Enterococcus were investigated. The results are presented in Table 1 . The activities of protease, acid invertase, and alkaline invertase were not observed, while the activity of amylase was not observed for $E$. hirae KGPMF9. The activity of alkaline phosphatase was not observed for KGPMF47 and KGPMF48 isolates. This result suggests that the tested isolates of enterococci showed no proteolytic activity. The results indicated that the isolates showed weak and strain-specific enzymatic activities.

In this paper, the enzymatic activities of LAB isolated from Sokobanja cheese (Southeastern Serbia) were evaluated. Also, the role of produced enzymes in the specific cheese flavor was assessed. As classified by Muruzović et al. (2018a), this cheese belongs to a group of full-fat, acid-curd soft cheeses. The detection of the enzymatic activities of the isolates was crucial since the bacteria in a different natural environment demonstrated the potential for becoming good producers of extracellular enzymes. So far, it has been demonstrated that enzymes play a very important role in food quality (Avendaño et al., 2016). Microbial enzymes have been used in various fields, such as chemical, agricultural, and biopharmaceutical industries. 
Table 1.

Enzymatic activities of LAB isolates

\begin{tabular}{|l|l|l|l|l|l|}
\hline Isolates & $\begin{array}{l}\text { Protease } \\
(\mathrm{IU} / \mathrm{ml})\end{array}$ & $\begin{array}{l}\text { Acid } \\
\text { invertase } \\
(\mathrm{IU} / \mathrm{ml})\end{array}$ & $\begin{array}{l}\text { Alkaline } \\
\text { invertase } \\
(\mathrm{IU} / \mathrm{ml})\end{array}$ & $\begin{array}{l}\text { Amylase } \\
(\mathrm{IU} / \mathrm{ml})\end{array}$ & $\begin{array}{l}\text { Alkaline } \\
\text { phosphatase } \\
(\mathrm{IU} / \mathrm{ml})\end{array}$ \\
\hline Lb. fermentum KGPMF28 & $5.8 \pm 0.00$ & $0 \pm 0.00$ & $0 \pm 0.00$ & $0.564 \pm 0.00$ & $0.006 \pm 0.00$ \\
\hline Lb. fermentum KGPMF29 & $2.1 \pm 0.00$ & $0 \pm 0.00$ & $0 \pm 0.00$ & $0.257 \pm 0.00$ & $0.005 \pm 0.00$ \\
\hline Lb. brevis KGPMF35 & $1.4 \pm 0.00$ & $0 \pm 0.00$ & $0 \pm 0.00$ & $0.135 \pm 0.00$ & $0.003 \pm 0.00$ \\
\hline Lb. plantarum KGPMF62 & $2.3 \pm 0.00$ & $0 \pm 0.00$ & $0 \pm 0.00$ & $0.301 \pm 0.00$ & $0.002 \pm 0.00$ \\
\hline Lc. lactis subsp. lactis KGPMG23 & $0.7 \pm 0.00$ & $0.03 \pm 0.00$ & $0 \pm 0.00$ & $0 \pm 0.00$ & $0.004 \pm 0.00$ \\
\hline $\begin{array}{l}\text { Lc. lactis subsp. lactis biovar. } \\
\text { diacetylactis KGPMG50 }\end{array}$ & $3.9 \pm 0.00$ & $0.035 \pm 0.00$ & $0 \pm 0.00$ & $0 \pm 0.00$ & $0 \pm 0.00$ \\
\hline $\begin{array}{l}\text { Lc. lactis subsp. lactis biovar. } \\
\text { diacetylactis KGPMG54 }\end{array}$ & $5.3 \pm 0.00$ & $0.03 \pm 0.00$ & $0 \pm 0.00$ & $0 \pm 0.00$ & $0.002 \pm 0.00$ \\
\hline $\begin{array}{l}\text { Lc. lactis subsp. lactis biovar. } \\
\text { diacetylactis KGPMG55 }\end{array}$ & $4.6 \pm 0.00$ & $0.017 \pm 0.00$ & $0 \pm 0.00$ & $0 \pm 0.00$ & $0.006 \pm 0.00$ \\
\hline $\begin{array}{l}\text { Lc. lactis subsp. lactis biovar. } \\
\text { diacetylactis KGPMG57 }\end{array}$ & $5.2 \pm 0.00$ & $0.04 \pm 0.00$ & $0 \pm 0.00$ & $0 \pm 0.00$ & $0.010 \pm 0.01$ \\
\hline $\begin{array}{l}\text { Lc. lactis subsp. lactis biovar. } \\
\text { diacetylactis KGPMG59 }\end{array}$ & $4.2 \pm 0.00$ & $0.09 \pm 0.00$ & $0 \pm 0.00$ & $0 \pm 0.00$ & $0.002 \pm 0.00$ \\
\hline E. hirae KGPMF9 & $0 \pm 0.00$ & $0 \pm 0.00$ & $0 \pm 0.00$ & $0 \pm 0.00$ & $0.014 \pm 0.01$ \\
\hline E. durans KGPMF10 & $0 \pm 0.00$ & $0 \pm 0.00$ & $0 \pm 0.00$ & $0.216 \pm 0.00$ & $0.006 \pm 0.00$ \\
\hline E. faecium KGPMF14 & $0 \pm 0.00$ & $0 \pm 0.00$ & $0 \pm 0.00$ & $0.186 \pm 0.00$ & $0.007 \pm 0.01$ \\
\hline E. faecalis KGPMF47 & $0 \pm 0.00$ & $0 \pm 0.00$ & $0 \pm 0.00$ & $0.208 \pm 0.00$ & $0 \pm 0.00$ \\
\hline E. faecalis KGPMF48 & $0 \pm 0.00$ & $0 \pm 0.00$ & $0 \pm 0.00$ & $0.230 \pm 0.00$ & $0 \pm 0.00$ \\
\hline E. faecalis KGPMF49 & $0 \pm 0.00$ & $0 \pm 0.00$ & $0 \pm 0.00$ & $0.243 \pm 0.00$ & $0.005 \pm 0.00$ \\
\hline
\end{tabular}

The values are presented as mean \pm standard deviation

In the case of cheese ripening, the formation of flavors is a slow process that involves various chemical and biochemical conversions of milk components. There are three main pathways in the conversion of milk components: the conversions of lactose (glycolysis), fat (lipolysis), and caseins (proteolysis). The starter cultures used in these fermentations ( $L C$. lactis, Lactobacillus sp., Streptococcus thermophilus) are the main source of the enzymes involved in these pathways (Bockelmann and Hoppe Seyler 2001). Lactobacilli, originating from the milk environment, might grow in the dairy products and participate in enzyme activities which lead to the formation of flavors and can play a crucial role in the ripening of cheese (Smit et al. 2005). Muruzović et al. (2018a; 2018b) investigated acidification ability in pure milk and milk enriched with $2 \%$ glucose and $1 \%$ yeast extract and showed that LAB isolates from Sokobanja cheese had good acidification ability. The best activity was shown by lactobacilli. In this paper, lactobacilli had significantly better enzymatic activity than the other two tested genera.

LAB contributes relatively little to lipolysis (Molimard and Spinnler, 1996; Medina et al., 2001), which was confirmed in this study because the LAB demonstrated no lipolytic activity.

Lb. plantarum isolated from Genestoso cheese showed strong caseinolytic activity (González et al., 2007). In this paper, proteolytic activity significantly differed between the genera of LAB and between the strains of the same genus. Lactobacilli and lactococci showed proteolytic activity, while enterococci showed no proteolytic activity. These findings confirmed previous screening results. Several strains of the genus Lactococcus showed greater proteolytic activity than some lactobacilli. These results are consistent with studies reported by Herreros et al. (2003) and González et al. (2010). The results in our study indicated no significant difference in protease activity between lactobacilli and lactococci isolates.

Amylolytic LAB influenced food processing industries, especially in the production of food additives such as organic acids (lactic acid) and enzymes ( $\alpha$-amylase) (Panda and Ray 2018). LABs with amylase activity are much sought after because they can reduce the cost of substrate pretreatment (Shibata et al. 2007). Shin et al. (2008) indicated that LAB from the genus Enterococcus showed high amylase activity, which was confirmed in our study.

Todorov et al. (2017) investigated the activity of alkaline phosphatase among lactobacilli isolated from Bulgarian lukanka (the meat product) and showed that activities were not exhibited by most of the tested strains. The best activity was shown for $L b$. brevis strains. Also, Medina et al. (2001) showed that lactococci isolated from milk and cheeses from Argentina had a good activity of alkaline phosphatase. Our study indicated that lactobacilli had a good activity of alkaline phosphatase, while the activity among lactococci and enterococci was strain specific.

It is well-known that LABs have the ability to produce some extra-cellular proteins, which include bacteriocins, enzymes, lipoproteins, and surface layer proteins (Kleerebezem et al., 2010), which is essential for their survival in different ecological niches (Zhou et al., 2010). Research by Muruzović et al. (2018c) indicated that LAB isolates from Sokobanja cheese possess the ability to survive environmental stress conditions. Based on the research results on their enzymatic activities, LAB isolates have the potential for use in biotechnology.

\section{Conclusion}

Since the tested cheese was made without adding bacterial starter cultures, it could be concluded that enzymes of the LAB had a role in the degradation of 
caseins, which led to flavor formation in cheese. It was established that the tested isolates showed no lipolytic activity. The activity of the other tested enzymes was strain specific. This study demonstrated that Sokobanja cheese is a potential resource for the isolation of LAB enzyme producers, which can be used as starter cultures. The results of this study contribute to a better knowledge of possibilities for further investigation of $\mathrm{LAB}$, which is important for the detection of potential new starter cultures in the dairy industry or their application in biotechnology.

\section{Acknowledgments}

This investigation was supported by the Ministry of Education, Science and Technological Development of the Republic of Serbia ((Agreement No. 451-0368/2020-14/200122).

\section{References}

Allen, R.J.L. (1940). The estimation of phosphorus. Biochemistry Journal, 34, 858-865.

Anson, M.L. (1938). The estimation of pepsin, trypsin, papain and cathepsin with hemoglobin. The Journal of General Physiology, 20, 79-89.

Avendaño, K.A., Anguiano, M., López, E.C., Montañez, L.E., Sifuentes, L., Balagurusamy, N. (2016). Microbial enzymes: Applications in food processing. Agro Food Industry Hi Tech, 27, 1-63.

Bernfeld, P. (1955). Amylases, $\alpha$ and $\beta$. Methods Enzymology, 1, 149-158.

Bockelmann, W., Hoppe Seyler, T. (2001). The surface flora of bacterial smear-ripened cheeses from cow's and goat's milk. International Dairy Journal, 11, 307-314.

Fox, P.F., McSweeney, P.L.H., Lynch, C.M. (1998). Significance of non-starter lactic acid bacteria in Cheddar cheese. Australian Journal of Dairy Technology, 53, 83-89.

González, L., Sacristán, N., Arenas, R., Fresno, J.M., Tornadijo, M.E. (2010). Enzymatic activity of lactic acid bacteria (with antimicrobial properties) isolated from a traditional Spanish cheese. Food Microbiology, 27, 592-597.

González, L., Sandoval, H., Sacristán, N., Castro, J.M., Fresno, J.M., Tornadijo, M.E. (2007). Identification of lactic acid bacteria isolated from Genestoso cheese throughout ripening and study of their antimicrobial activity. Food Control, 118, 716-722.

Grujović, M., Mladenović, K., Žugić Petrović, T., Čomić, Lj. (2019). Assessment of the antagonistic potential and ability of biofilm formation of Enterococcus spp. isolated from Serbian cheese. Veterinarski arhiv, 89(5), 653-667.

Harrigan, W.F., McCance, M.E. (1976). Laboratory methods in food and dairy microbiology. Academic Press, London, UK. pp. 170-210.

Herreros, M.A., Fresno, J.M., González Prieto, M.J., Tornadijo, M.E. (2003). Technological characterization of lactic acid bacteria isolated from Armada cheese (a Spanish goats' milk cheese). International Dairy Journal, 13, 469-479.

Kenny, O., Fitz Gerald, R.J., O'Cuinn, G., Beresford, T., Jordan, K. (2003). Growth phase and growth medium effects on the peptidase activities of Lactobacillus helveticus. International Dairy Journal, 13, 509-516.

Kleerebezem, M., Hols, P., Bernard, E., Rolain, T., Zhou, M. (2010). The extracellular biology of the lactobacilli. FEMS Microbiol Review, 13, 199-230.

Liu, L., Yang, H., Shin, H., Chen, R.R., Li, J., Du, G., Chen, J. (2013). How to achieve high-level expression of microbia enzymes: strategies and perspectives. Bioengineered, 4, 212-223.

Medina, R.M., Gonzalez, K.S., Oliver, G. (2001). Characterization of the lactic acid bacteria in ewe's milk and cheese from Northwest Argentina. Journal of Food Protection, 64, 559-563.
Miller, G.L. (1959). Use of dinitrosalicylic acid reagent for determination of reducing sugar. Analytical Chemistry, 31, 426-428.

Molimard, P., Spinnler, H.E. (1996). Compounds involved in the flavour of surface mold-ripened cheeses: Origins and properties. Journal of Dairy Science, 79, 169-184.

Mtshali, P.S. (2007). Screening and characterisation of winerelated enzymes produced by wine-associated lactic acid bacteria. MSc. Thesis, Stellenbosch University, Matieland, South Africa.

Muruzović, M.Ž., Mladenović, K.G., Žugić Petrović, T., Čomić, L.R. (2018a). Characterization of lactic acid bacteria isolated from traditionally made Serbian cheese and evaluation of their antagonistic potential against Enterobacteriaceae. Journal of Food Processing and Preservation, DOI: 10.1111/jfpp.13577

Muruzović, M.Ž., Mladenović, K.G., Djilas, M.D., Stefanović, O.D., Čomić, L.R. (2018b). In vitro evaluation of antimicrobial potential and ability of biofilm formation of autochthonous Lactobacillus spp. and Lactococcus spp. isolated from traditionally made cheese from Southeastern Serbia. Journal of Food Processing and Preservation, DOI: 10.1111/jfpp.13776

Muruzović, M.Ž., Mladenović, K.G., Čomić, L.R. (2018c). In vitro evaluation of resistance to environmental stress by planktonic and biofilm form of lactic acid bacteria isolated from traditionally made cheese from Serbia. Food Bioscience, 23, 54-59.

Novik, G., Astapovich, N., Ryabaya, N. (2007). Production of hydrolases by lactic acid bacteria and bifidobacteria and their antibiotic resistance. Applied Biochemistry and Microbiology, 43, 164-169.

Panda, S.H., Ray, R.C. (2018). Amylolytic lactic acid bacteria microbiology and technological interventions in food fermentations. In: Montet D., Ray R.C. (eds.), Fermented Foods: Part 1, Biochemistry \& Biotechnology Edition, CRC Press, Boca raton, USA, pp. 149-151.

Patel, A., Shah, N., Prajapat, J.B. (2013). Biosynthesis of vitamins and enzymes in fermented foods by lactic acid bacteria and related genera - A promising approach. Croatian Journal of Food Science and Technology, 5, 85-91.

Patel, A.R., Lindström, C., Patel, A., Prajapati, J.B., Olle H. (2012). Probiotic properties of exopolysaccharide producing lactic acid bacteria isolated from vegetables and traditional Indian fermented foods. International Journal of Fermented Foods, 1, 87-101.

Peterson, S.D., Marshall, R.T. (1990). Nonstarter lactobacilli in Cheddar cheese. Journal of Dairy Science, 73, 1395-1410.

Shibata, K., Flores, D.M., Kobayashi, G., Sonomoto, K. (2007). Direct l-lactic acid fermentation with sago starch by a novel amylolytic lactic acid bacterium, Enterococcus faecium. Enzyme and Microbial Technology, 41, 149-155.

Shin, M.S., Han, S.K., Ji, A.R., Kim, K.S., Lee, W.K. (2008). Isolation and characterization of bacteriocin-producing bacteria from the gastrointestinal tract of broiler chickens for probiotic use. Journal of Applied Microbiology, 105, 2203-2212.

Smit, G., Smit, B.A., Engels, W.M.J. (2005). Flavour formation by lactic acid bacteria and biochemical flavour profiling of cheese products. FEMS Microbiology Review, 29, 591-610.

Sumner, J.B., Howell, S.F. (1935). A method for determination of saccharase activity. The Journal of Biological Chemistry, $108,51-54$

Todorov, S.D., Stojanovski, S., Iliev, I., Moncheva, P., Nero, L.A., Ivanova I.V. (2017). Technology and safety assessment for lactic acid bacteria isolated from traditional Bulgarian fermented meat product "lukanka". Brazilian Journal of Microbiology, 48, 576-586.

Wijesundera, C., Roberts, M., Limsowtin, G.K.Y. (1997). Flavour development in aseptic cheese curd slurries prepared with single-strain starter bacteria in the presence and absence of adjuncts. Lait- IDF Symposium "Ripening and Quality of Cheeses", Besançon, France, 77: 121-131.

Zhou, M., Theunissen, D., Wels, M., Siezen R. (2010). LABsecretome: a genome scale comparative analysis of the predicted extracellular and surface associated proteins of lactic acid bacteria. BMC Genomics, 11, 651. 